\title{
Interaction between karstic aquifers and allogenic rivers: The aquifer of the national park of the ephemeral river Lobos Canyon (Spain)
}

\author{
Eugenio Sanz Pérez, Ignacio Menéndez Pidal", Rafael Segovia Rosales \\ Applied Geology Laboratory, Civil Engineering Higher Technical School, Polytechnic University of Madrid, Madrid, Spain; \\ *Corresponding Author: impidal@caminos.upm.es, esanz@,caminos.upm.es, rsegovia@ohl.es
}

Received 21 December 2012; revised 21 January 2013; accepted 4 February 2013

\begin{abstract}
A methodology is described for understanding the interaction of karstic aquifers with allogenic rivers, where little information is available. This methodology includes conventional hydrogenology methods tracer tests and measurements of flow into, out of and circulating within the karstic system. The method is designed to understand the hydrogeological behaviour of a river in sufficient detail, given a short study period. The methodology is applied to a karstic system in Spain, obtaining useful, quantitative results for a hydrological year, such as an estimate of the water balance, differentiation between autogenic and allogenic natural recharge, relationship and connection between the river and the aquifer, and measurements of infiltration capacity in watercourses under different hydrological situations. The paper deals with a useful example that could be applied to other rivers and aquifers where few data are available. It can be applied to aquifers under a natural regime and Mediterranean climate.
\end{abstract}

Keywords: River-Aquifer Relationship; Water Balance; Natural Recharge; Karst Hydrology; Mediterranean Climate

\section{INTRODUCTION AND OBJECTIVES}

Interactions between groundwater and surface water basically proceed in three ways: groundwater flows through the streamed into the stream (gaining stream), stream water infiltrates through the sediments into the groundwater (losing streams), and ephemeral stream, where the water table is below the streambed, especially in karstic aquifers and arid river basins. The ephemeral rivers flow due to a response to intense rainfall or allogeneic rivers entries in a karstic system, i.e. Rio Lobos
Canyon (Spain). Even in arid climates, the headwaters have ephemeral streams in steeper areas (Barlow and Dickerman, 2001, Granato et al., 2003) [1,2].

For the protection of water resources it is important to understand and quantity exchange processes and pathways between groundwater and surface water. Numerous methods exist for estimating fluxes at the groundwater-surface water interface. Scalon et al. (2002) [3] presented an overview of techniques for quantifying groundwater recharge on different space and time scales. Kalbus et al. (2006) [4] provide also an overview of the methods that are currently applied for estimating fluxes at the groundwater-surface interface. The methods are grouped into direct measurements of water flux, heat tracer methods, methods based on Darcy's law, mass balance approach and modelling approaches.

Stream aquifer interactions are complex in space as well as in time. Changes of the rock substratum conductivity, permeability of stream sediments, and seasonal variations in precipitation and evapotranspiration patterns can alter water tables and thereby cause changes in the direction of exchange flows (Lerner et al., 1990) [5].

The mechanism of the loss of water in a river ephemeral is a transitional process. This is produced by a pulse of infiltration or saturation front which goes down during a significant storm. This infiltration pulse changes very quickly and is very difficult to measure (Abdulrazzak and Morel-Seytoux, 1953; Freyberg, 1983) [6,7]. Intermittent streams may be caused by regional groundwater level fluctuations over time causing the river to be a winner or loser (Winter et al., 1998) [8]. An extreme situation are the poljes in karst regions that are dry valleys where water infiltrates the surface during the dry season and becomes flooded valley during wet periods in which sinks become sources.

Methods of assessing losses in ephemeral channels are based on the conceptualization of the flow (Freyberg, 1983; Lerner et al., 1990) [5,7] methods that record changes in soil temperature and water (Stonestrom and 
Constantz, 2004) [9] and gravimetric methods (Goodrich et al., 1997) [10].

The dynamics of ephemeral stream-aquifer interaction are still relatively poorly understood. In a few cases have been developed quantitative studies (Goodrich et al., 1997) [10], which quantified water loss along an ephemeral river flow measured in consecutive gauging stations.

In the Spanish Mediterranean basins there are large areas without permanent rivers, many of them are ephemeral rivers that are usually dry, but periodically have floods.

Karstic aquifers are a source of water resources in large parts of the Mediterranean region. The Mediterranean climate is characterized by scarce, irregular rainfall (600 - $800 \mathrm{~mm} /$ year), hot summers and mild winters. Karstic systems typically exhibit variable hydrological conditions through the year, and from year to year. It is frequently the case for rivers in such systems to be losing streams over long periods. It is also frequent that the aquifers drain through large karstic springs under natural regime, which contribute to the base flow and water quality of the river. There are other aquifers, intensively exploited for human water supply, whose vulnerability to pollution needs to be defined and protection zones instated.

A large proportion of karstic systems are scarcely exploited, and under near natural regime, with greater or lesser hydraulic connection with rivers. Some of these large springs, such as La Galiana (Iberian Cordillera, Soria, Spain), represent the only drainage point for aquifers. They contain significant resources of high quality and are responsible for the majority of the base flow of the rivers they give rise to, since the Mediterranean climate is quite arid and precipitation is irregular. These watercourses can also be home to a well-conserved aquatic fauna, whose survival depends to a large degree on the base flow. This type of aquifer also requires significant hydrogeological study.

The study area dealt with in this paper lies in the northwest of the Iberian Cordillera, Central Spain, and extends over approximately $400 \mathrm{~km}^{2}$ (Figures 1 and 2) The relief is determined by the presence of a meseta of limestone layers that have been dissected by the river Lobos, giving rise to a canyon 26 kilometres long. In 1985, the canyon was declared a Natural Park, due to its peculiar landscape and important colonies of Griffin Vulture and Golden Eagle. La Galiana spring, at the downstream end of the canyon, drains a mean flow of some $2000 \mathrm{l} / \mathrm{s}$, giving rise to the river Ucero, a right-bank tributary of the river Duero. Similarly, the river Lobos has a series of left-bank tributaries, whose headwaters lie outside of the calcareous massif in the less permeable rocks surrounding it.

Most of the Cretaceous karstic aquifers and their re- charge areas fall within the boundaries of the Natural Park. One of the main objectives of declaring the Natural Park was to conserve its waters and achieve compatible use of the aquifer as a groundwater reserve for supply high-quality water to the centres of population in the vicinity. Although the groundwater resources of the Weald Facies around the periphery of the karst would be sufficient in quantity to satisfy current demand, they are mostly degraded by the naturally-poor quality of water, due to their high iron content. For this reason, the karstic aquifer of the Lobos Canyon assumes greater importance as a water resource and as a significant water reserve suitable for human consumption, which need to be protected from contamination.

The object of this study was to provide a sufficientlydetailed understanding of the water balance of the system and the interaction between karstic aquifer and associated rivers over a short period of time, taking into account the scarcity of available data. For this reason, it was necessary to devise a plan of work that could yield quantitative knowledge and include aspects important to the future management and conservation of the aquifer and its rivers, such as.

Detailed evaluation of the water balance over eleven months approximately (341 days, from 12/10/1995 to 07/03/1996), with emphasis on the determination of the natural recharge. One hydrological year is clearly insufficient to evaluate the mean groundwater resources of an aquifer, but this was not the main objective, since the zone clearly has surplus water, and there is plenty to meet water demand. There is a permanent gauging station on the river Ucero $20 \mathrm{~km}$ downstream of La Galiana spring, which measures the flow downstream of where other tributaries join it, and so it is not representative of
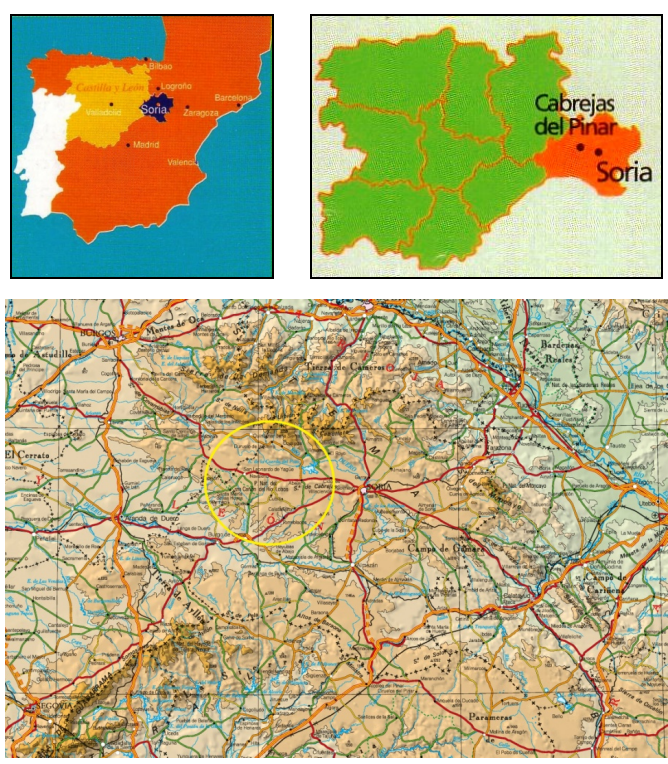

Figure 1. Situation of the study area. 


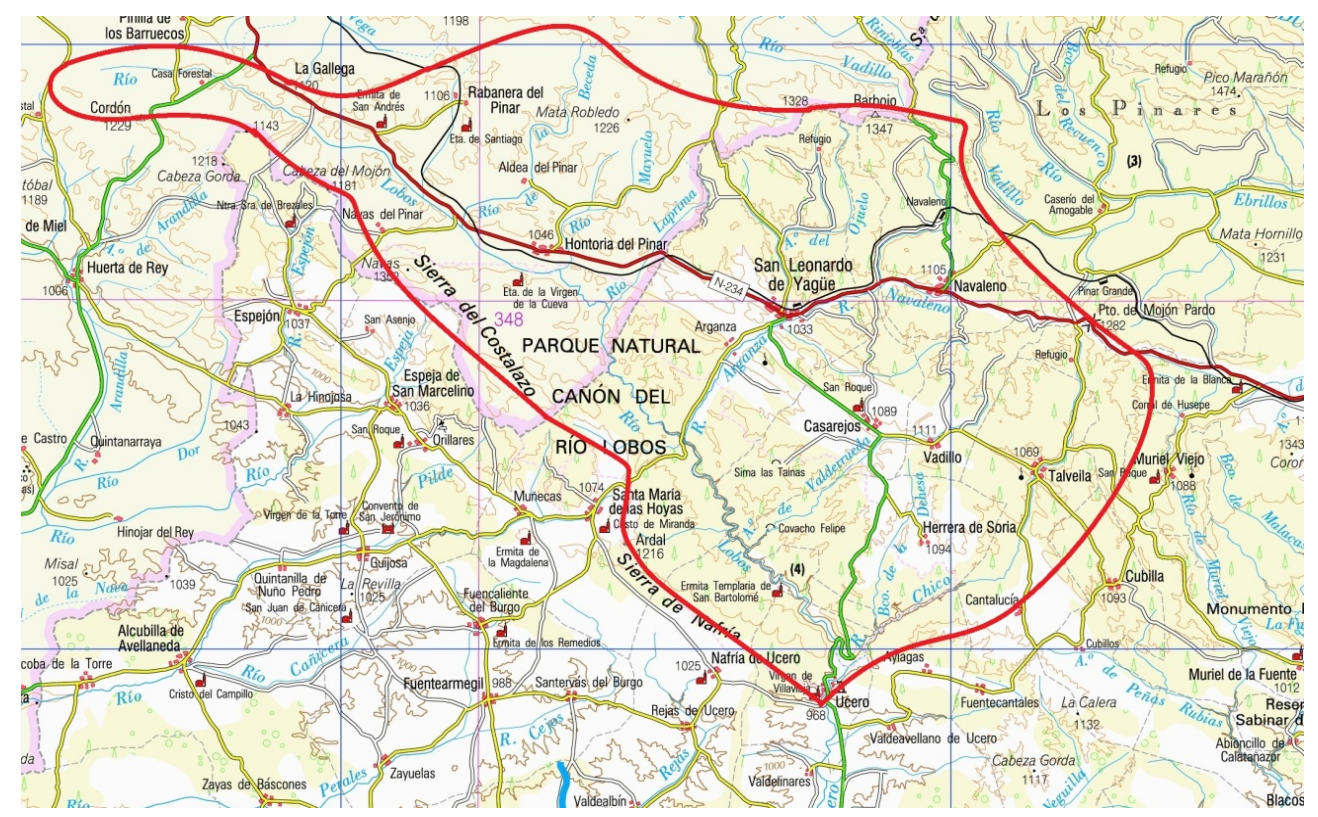

Figure 2. Watershed Lobos River Canyon at the study area.

all of the outflows of the aquifer. Like many other aquifers, there is no permanent, continuous gauging station at the springheads, nor on the rivers that run through it. Thus, to determine its mean resources, a rainfall-run-off model can be applied to reconstruct the phoronomic series. The principal focus at the outset of the study was to quantify the natural allogenic and autogenic recharge separately, and to understand exactly how each is produced, by monitoring several provisional gauging stations of both the karst's allogenic rivers, and the outflows of the aquifer.

It must be remembered that the area of autogenic recharge of the aquifer is largely forested and, therefore, the risk of pollution is more likely to come from discharges to the allogenic rivers that flow through towns and villages before infiltration into the karstic system.

Another important aim was to gain a detailed knowledge of the hydrogeological relationship between the river Lobos and the karstic aquifer under different hydrological situations, given that this river crosses the aquifer from one side to the other. It was not known if it behaved only as a losing stream along its entire length, nor what the infiltration capacity of its river bed was. Tracing studies were required to elucidate the hydraulic connection between the rivers and the aquifer (Segovia et al., 2011) [11].

\section{METHODOLOGY}

Of the conventional hydrogeological methods, we catalogued 239 water points, including all the points in the karstic aquifer, most of those in the catchments on the northern perimeter that provide allogenous recharge, as well as some on the southern edge of the aquifer that correspond to the border with the Tertiary of the Duero Basin. This inventory also includes resurgences and swallow holes containing water, considering these as "natural wells". All of the deep potholes have been explored by speleologists in order to identify the regional phreatic levels, as it was already known that there are no significant hanging levels. Dry swallow holes were also included, considering "negative wells" as those whose bases were not wet even when the piezometric level rises under high water conditions.

The inventory of water points was made in both wet and dry seasons, in order to identify temporary springs. The most representative springs were selected from those inventoried for flow gauging, using cup-type meters (or helical flow meters in the larger ones).

We were interested to establish a hydrogeological balance for the aquifer, by monitoring the variables involved, especially the groundwater discharges at the Galiana spring and the recharge from allogenic rivers. For this reason, five gauging stations were installed in the main watercourses that disappear into limestone, located just upstream of the river Lobos karst (Figures 2 and 3).

These gauges were placed to assess the allogenic recharge to the aquifer arising from the less permeable areas surrounding it, the majority of which belong to the Weald. Readings were taken daily to weekly depending on the point and the hydrological situation of the streams (they were sometimes dry) over a almost hydrological year (1995-1996). In addition, four flow gauging surveys were undertaken to calibrate the rating curve.

A gauge was installed at Puente de Siete Ojos, which represents an intermediate point on the river Lobos and 
from where it can be determined whether the river flow exceeds the infiltration capacity of the sinkholes in its upper reaches.

Systematic flow measurements were also made at $\mathrm{La}$ Galiana spring, as well as discontinuous water level measurements over a short time period in a borehole located in the central part of the aquifer.

All watercourses were walked at different times of year and under differing hydrological situations, in order to identify sink holes and possible zones of discharge, and so understand the hydrogeological behaviour of the surface water flows in the upper, middle and lower reaches. Differential gauging was also undertaken.

Experimental measurements correspond to a short period of time (eleven months) and cannot cover all hydrological conditions of the basin. For that reason we have added qualitative observations made from 1989 to the present (2012) both for the staff working in the Natural Park, as the authors of this work during numerous visits to the field. The summary of these observations are plotted in Figure 11.

An approximate isoline map was drawn, with elevations, of the base of the carbonate, in order to understand its geometry, and on the north-eastern border and confirm its isolation from the Tertiary.
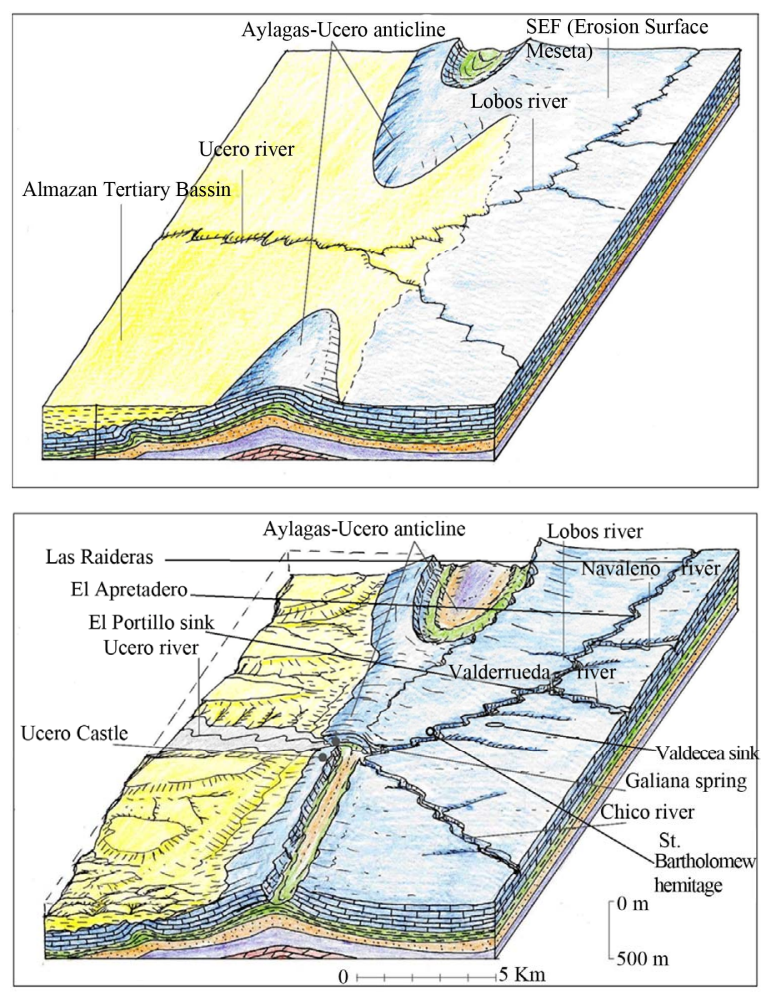

Figure 3. Block diagrams showing the down cutting of the Lobos river in the meseta during Quaternary. Blue: Upper Cretaceous limestone; Green: Upper Cretaceous marls; Brown and Purple: Utrillas Facies sands; Red: Jurassic dolomite limestone.

\section{NATURAL RECHARGE AND WATER BALANCE IN THE KARSTIC SYSTEM OF THE RIVER LOBOS CANYON}

\subsection{Hydrostratigraphi and Structure of the Karstic Aquifer}

Sedimentary terrains in the Natural Park date from the Jurassic to the Present Day. The Jurassic rocks are essentially marine carbonate rocks. Overlying these, and concordant with them and in transition towards the Cretaceous, are the detritic sediments of the Purbeck-Weald Facies. Over these are the sands of the Utrillas Facies (Albian), then Coniacian-Santonian-Campanian marls, and the Turonian limestones, which project to form the surface relief, and which form the cliff faces of the canyons in this region, such as the rivers Lobos, Espeja, Abión en Burgo de Osma, Boos, etc. Above these strata comes the Garumnian Facies in transition with the Tertiary and, discordantly, the postorogenic sediments of the Miocene, Plioquaternary and Quaternary (IGME, 1956, 1982) [12-14].

The Coniacian-Santonian-Campanian limestones are $240 \mathrm{~m}$ thick and comprise a hydrostratigraphic unit of high permeability that forms the main aquifer. Its impermeable base consists of a marly series with calcareous intercalations towards the top, some $70-100 \mathrm{~m}$ thick.

Due to the presence of the marly intercalations, the lower part of the aquifer can be locally confined, while the rest is classified as a free aquifer, forming a meseta, with a syncline structure oriented east-west. Its lateral borders are the impermeable Cretaceous marly outcrops that also form the aquifer's base, except in the south, where there is a discordant contact between the clayey Miocene and the calcareous Upper Cretaceous. The anticlinal axis of Santa María of the Hoyas-Ucero-Aylagas raises the marly base and, whilst it does not always outcrop, it makes the hidden lateral barrier, and the hinge and axis of the anticlinal make the underground watershed between the Lobos aquifer in the north, and the one to the south that feeds the springs at Rejas, Fuencaliente and Ucero. This behaviour was deduced from elevations, as indicated in the block diagram in Figures 3-5.

The eastern border may be open towards Torreblancos, where springs of $200 \mathrm{l} / \mathrm{s}$ emerge, and so we opted to fix the limit of the system where the Cretaceous is covered by the Tertiary. In any case, one cannot rule out the possibility of a hydraulic connection with the Tertiary of the Almazán Basin.

The marls mentioned above mark the base of the karst, surrounding the synform on almost all sides. Where this limit occurs at a lower elevation (approximately $900 \mathrm{~m}$, at the entrance to the Lobos Canyon, upstream of Ucero), is where La Galiana spring emerges. 


\subsection{Natural Recharge and Water Balance}

\subsubsection{Characterization of the Natural Recharge}

The catchment of the river Lobos can be divided into two completely different zones with distinct hydrogeological characters:

1) The Wealden deposits and Jurassic carbonates, located in the north and northeast comprises mostly detritic deposits (Wealden), and a narrow series of Jurassic carbonates. It forms a watershed with the river Ebrillos to the northeast and the tributaries of the river Arlanza to the north. It is a hilly area of leafy pine forest. It receives similar or slightly higher precipitation, has greater surface runoff and a somewhat similar hydrogeological be-

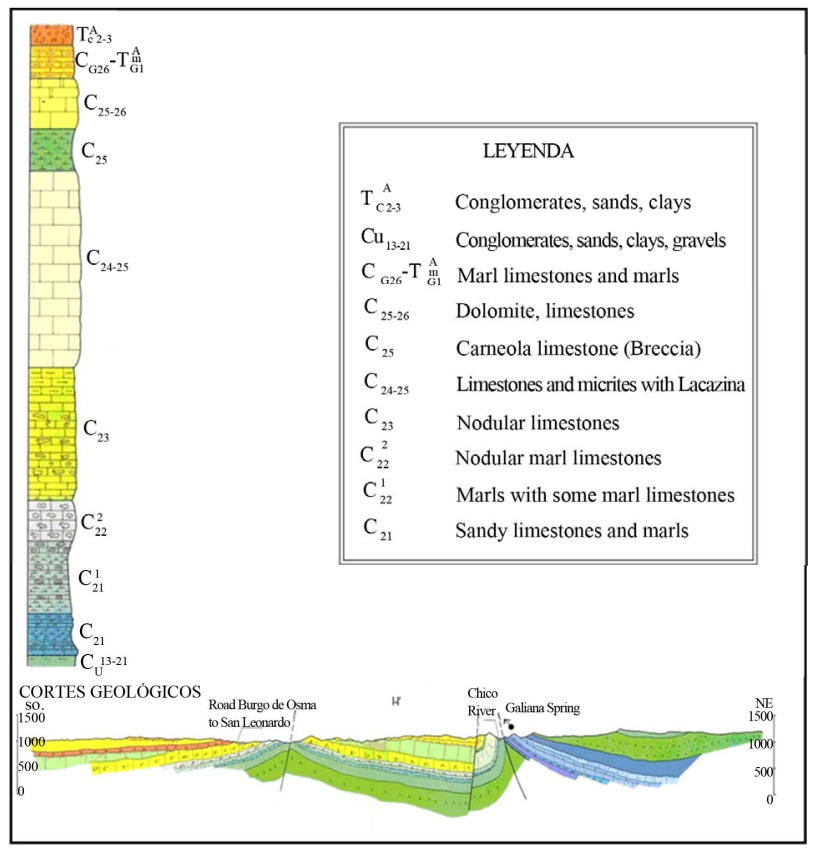

Figure 4. Geological interpretation of study area showing envolved lithology and stratigraphy.

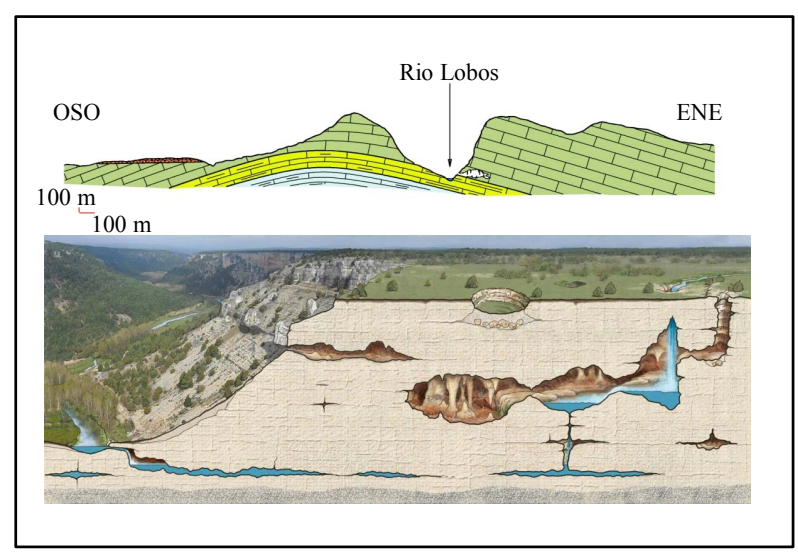

Figure 5. Geological cross-section showing an interpretation of water flow near La Galiana spring. Detailed diagram block along same geological cross-section. haviour to the large sedimentary catchments. Its outflows, both surface runoff and groundwater base flow (hypodermic water), flow into the karst, since the headwaters of the rivers Lobos, Navaleno, Chico and others all flow into the Lobos karstic zone.

2) The karstic zone delimits the catchment in the south and southeast by permeable layers of low permeability. It receives slightly less rainfall. It discharges mainly towards La Galiana spring, but also to the springs at Rejas de Ucero, Santervás and Fuencaliente in the south; one cannot rule out a small southward groundwater transfer towards the Tertiary of the Almazán Basin on the lowlands of the river Ucero.

This zone does not produce surface runoff, except after very intense rainfall. In addition, recharge from precipitation falling over its outcrops goes entirely to the Wealden/Jurassic zone. When the infiltration capacity of the watercourses of the river Lobo and river Chico in the other zone is exceeded, excess surface water leaves the karstic system along the river Ucero.

The surface areas of the two zones are:

Karstic zone: $164 \mathrm{~km}^{2}$

Wealden zone and Jurassic carbonate: $197 \mathrm{~km}^{2}$

TOTAL: $361 \mathrm{~km}^{2}$.

\subsubsection{Allogenic Recharge}

Given that the peripheral Wealden zone is in part of the catchment that is under natural regime, flow gauging of its streams was done to provide basic information for a hydrological study of both this and the karstic zone.

The gauging survey lasted eleven months approximately (341 days, from 12/10/1995 to 07/03/1996), undertaken along the main rivers and streams that descend from the north and north-eastern periphery. Gauges were installed at the following points.

Lobos River, at Hontoria del Pinar (Burgos), just before it enters into the karstic system of the Lobos Canyon. The catchment covers $80 \mathrm{~km}^{2}$ corresponding to the headwaters of the Lobos. Gauging was done to characterize and quantify the inflow from the detritic Wealden and Jurassic carbonate terrains. It also allowed for differential gauging with the station downstream at Puente de Siete Ojos, which lies within the karstic zone, in order to quantify losses or discharges in this stretch of the river.

Navaleno River, at Arganza (Soria), before this river enters the karst. Two gauges had to be installed, one in the natural course of the river Navaleno, and the other in the take-off to a mill that frequently draws water from the river. The two were summed to give the total flow for the river. The catchment covers $85 \mathrm{~km}^{2}$, consisting of detritic Wealden terrains and occasional Jurassic limestone and dolomite.

Valderrueda stream, at La Cantera bridge from Ucero to San Leonardo, before the stream is lost to the lime- 
stone of the karstic aquifer. Its catchment is small, some $12 \mathrm{~km}^{2}$ and comprises mostly detritic Wealden deposits. It serves as a representative catchment to indicate what the other small, non-gauged, periphery catchments could contribute.

Chico River at Talveila, before the river suffers its first losses as it enters the karstic aquifer. It drains $15 \mathrm{~km}^{2}$ and comprises solely detritic Wealden deposits.

In addition to the above stations monitoring allogenic inflows to the karst, two further stations were set up within the karstic aquifer itself.

Lobos River at Puente de Siete Ojos, upstream of the confluence with the river Navaleno. This station was designed to characterize the hydrogeological regime of the Lobos as it enters the Canyon, and to quantify the losses or inflows, calculated by difference between the headwater stations at Hontoria and the end of the canyon at Ucero. The catchment between Hontoria del Pinar and this point is $55 \mathrm{~km}^{2}$.

Ucero River at Ucero, downstream of the confluence with the river Chico. Effectively, it monitors the outflows of the system, consisting of the Galiana flow (princepally), the discharge of the river Lobos at La Galiana, and the surface discharge of the rivers Lobos and Chico. The surface area of the catchment as far as this station is $344 \mathrm{~km}^{2}$, which includes both the karstic zone $\left(164 \mathrm{~km}^{2}\right)$ and peripheral detritic zone $\left(180 \mathrm{~km}^{2}\right)$, commented above.

A gauge board was installed at each station and direct gauging was done under different hydrological conditions, including fierce floods, with the object of constructing the rating curve.

The total allogenic recharge of the gauged rivers amounted to an equivalent flow of $1049.01 \mathrm{l} / \mathrm{s}$. However, we must consider the other small peripheral catchments $\left(5 \mathrm{~km}^{2}\right)$ that were not gauged. These were assigned a value equivalent to the mean unitary flow of the gauged catchments $\left(6.1 \mathrm{l} / \mathrm{s} / \mathrm{m}^{2}\right)$. This amounts to a further $30.5 \mathrm{l} / \mathrm{s}$, which brings the total allogenic recharge to $1080 \mathrm{l} / \mathrm{s}$, which is equivalent to $31.8 \mathrm{hm}^{3}$ for the period considered, 341 days (Table 1).

The following section gives a detailed description of the hydrological regime of these losing rivers in the karst, and of their relationship with the gaining rivers of the detritic Wealden aquifer.

\subsubsection{Autogenic Recharge}

Recharge in the karstic zone is autogenic and diffuse over the $164 \mathrm{~km}^{2}$ of the outcrop. This is not to say that, in intense rainfall, there is no running water in the streams, but that this rapidly infiltrates into the streambeds.

The area of the outcrop apparently has a low degree of karstification, since there is no great profusion of dolines and uvalas. Nevertheless, the ground has a high absorp-
Table 1. Mean gauges flow and unitary flows in the peripheral catchments measured over the year 1995-1996 (from $12 / 10 / 1995$ to $07 / 03 / 1996)$.

\begin{tabular}{cccc}
\hline Peripheral catchments & $\begin{array}{c}\text { Surface area } \\
\left(\mathrm{km}^{2}\right)\end{array}$ & $\begin{array}{c}\text { Mean gauged } \\
\text { flow }(1 / \mathrm{s})\end{array}$ & $\begin{array}{c}\text { Unitary flow } \\
\left(1 / \mathrm{s} / \mathrm{m}^{2}\right)\end{array}$ \\
\hline $\begin{array}{c}\text { Headwaters of the } \\
\text { River Lobos }\end{array}$ & 80 & 92.3 & 1.15 \\
$\quad$ Río Navaleno & 85 & 759.7 & 8.9 \\
$\begin{array}{c}\text { Stream de Valderrueda } \\
\quad \text { Río Chico }\end{array}$ & 12 & 84.6 & 7.05 \\
$\begin{array}{c}\text { Other catchments } \\
\text { (streams of the Chorrón, } \\
\text { Cubilla, etc.) } \\
\text { TOTAL }\end{array}$ & 5 & 113.0 & 7.5 \\
\hline
\end{tabular}

tive capacity, as demonstrated by the fact that the upper meseta and its incipient drainage network is incapable of generating surface flows sufficient in quantity or duration to reach the river Lobos (though there are exceptions to this following heavy storms in the watercourses close to the river). Based on measurements of dripping from stalactites in the Upper and Lower Caves at La Galiana (situated on the same vertical plane but separated by a $100 \mathrm{~m}$ drop), it has been possible to observe the reaction of rainfall infiltration, which shows that it takes 4 or 5 days to cross the $100 \mathrm{~m}$ of unsaturated zone.

\subsubsection{Values of Allogenic and Autogenic Recharge and Water Balance}

To calculate recharge according to the water balance, the following equivalence must be established:

$$
E=S+-\Delta A
$$

where $E$ are the inputs to the system, $S$, the outflows, and $\triangle A$ is the variation in storage.

In our case, the inflows $(E)$ are the natural recharge from precipitation falling over the carbonate outcrops $\left(164 \mathrm{~km}^{2}\right)$, plus the allogenic recharge from the rivers and streams of the peripheral areas that flow into and are lost in the karst $\left(197 \mathrm{~km}^{2}\right)$. Rainfall over the carbonate outcrops was calculated for the period considered using the isohyets method for the five existing rainfall stations in and around the aquifer (Hontoria del Pinar, Navaleno, San Leonardo de Yagüe, Ucero and Santa Maria de las Hoyas). Rainfall was thus evaluated to be $A P=109.5 \mathrm{hm}^{3}$.

The outflows $(S)$ of the system, given that the aquifer operates under natural regime, are as follows.

Discharge of La Galiana spring and groundwater drainage into the river Ucero and Lobos. For the period $26 / 8 / 95$ to $31 / 8 / 96$ (341 days) this amounted to a mean flow $Q_{m}=2.689 \mathrm{l} / \mathrm{s}$, equivalent to $79.2 \mathrm{hm}^{3}$.

Surface runoff in the watercourses that leave the system, which in our case comprise only the flows of the river Lobos and the river Chico in spate conditions. Over 
the 1995-1996 hydrological year, this surface flow was estimated as $Q_{s}=120 \mathrm{l} / \mathrm{s}$, equivalent to $3.53 \mathrm{hm}^{3}$. This represents only $4.0 \%$ of the outflow from the system, which was calculated to be $88.73 \mathrm{hm}^{3}$ (79.2 and 3.53 $\mathrm{hm}^{3}$ ).

We can see that almost all of the outflow takes the form of underground runoff (96\%), even though a large part of this runoff comes from the surface runoff of the allogenic rivers, which become underground runoff during its transit of only a few days through the aquifer.

Groundwater transfer, which do not appear to be significant, given the impermeable geology surrounding the aquifer (except the terrains on the southeastern boundary).

Water abstractions from aquifer, which are practically non-existent.

The emptying of the water stored in the aquifer $(\Delta V)$ must be taken into account because the period considered is short. This variation was determined from the difference between the hydrodynamic volumes $(V o)$ at the start and end of the periods, considered as:

$$
V o=Q / \alpha
$$

where $Q$ is discharge and $\alpha$ is drainage coefficient. At this case, $\alpha=0.0085$ day $^{-1}$ and is estimated from obtained hydrograms.

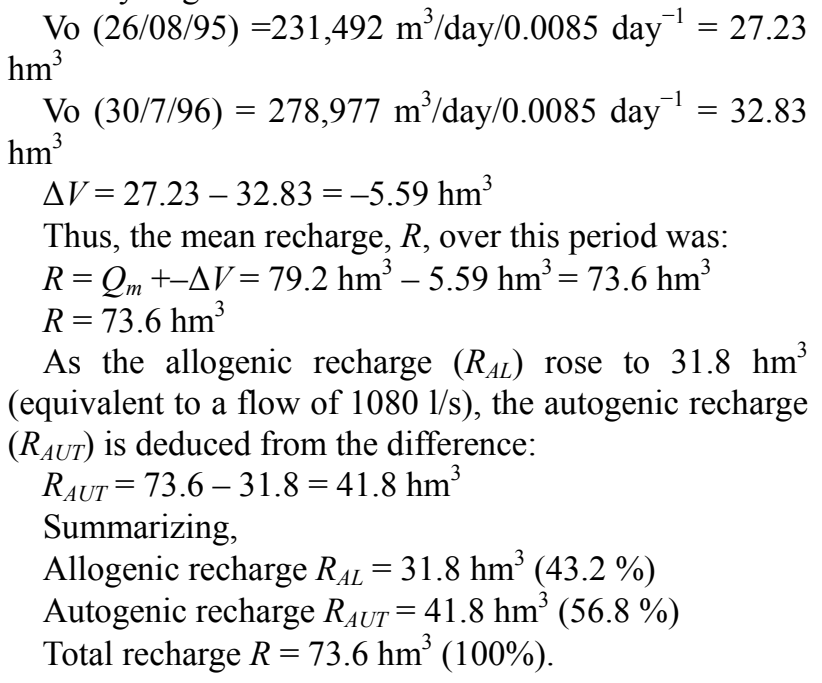

\subsubsection{Water Balance}

Thus, the water balance of the aquifer is under natural regime, without any borehole abstractions, and the balance for the quasi-hydrological year 1995-1996 (341 days) can be established as:

Rainfall input: $109.5 \mathrm{hm}^{3}$

Natural recharge: $73.6 \mathrm{hm}^{3}$

Groundwater discharges: $79.2 \mathrm{hm}^{3}$

Surface runoff $(*): 0 \mathrm{hm}^{3}$

Evapotranspiration (**): $67.7 \mathrm{hm}^{3}$

Pumped groundwater abstractions: $0 \mathrm{hm}^{3}$ (negligible)
Transfers to other aquifers: $0 \mathrm{hm}^{3}$

Storage in the aquifer: $-5.59 \mathrm{hm}^{3}$.

$\left.{ }^{*}\right)$ It is assumed that the surface runoff measured at Ucero comes from the allogenic catchments (i.e., it is not generated within the karst).

$(* *)$ It is the difference between the rainfall and the autogenic recharge in the karst $E T=109.5,-41.8=67.7$ $\mathrm{hm}^{3}$.

\subsubsection{Estimate of Natural Recharge with Respect to Precipitation}

The rate of recharge with respect to precipitation (TRP) can be defined by:

$T R P=R / A P$

where:

$R$ is the natural recharge.

$A P$ is the rainfall input of the recharge area of the aquifer, whether autogenic, or allogenic.

The rate of recharge in the karstic zone with respect to precipitation $\left(T R P_{k}\right)$ is therefore:

$T R P_{k}=R_{k} / A P_{k}$, where $R_{k}$ is the natural recharge in the karstic zone and $A P_{k}$, the rainfall input in the karstic zone.

$T R P_{k}=R_{k} / A P_{k}=41.8 / 109.5=0.382$.

Therefore, $T R P_{k}=38.2 \%$, a figure that seems in accordance with the lithology of aquifer.

The recharge rate in the non-karstic zone $\left(T R P_{A L}\right)$ will be:

$A P_{A L}=P_{A L} \times A_{A L}$

where

$P_{A L}$, is the mean precipitation in the non-karstic zone, $=685.5 \mathrm{~mm}$.

$A_{A L}$, is the area of the non-karstic zones, $=197 \mathrm{~km}^{2}$.

Thus:

$A P_{A L}=0.6855 \mathrm{~m} \times 197 \times 106 \mathrm{~m}^{3}=135.04 \mathrm{hm}^{3}$

$T R P_{A L}=R_{A L} / A P_{A L}=31.8 / 135.04=0.24=24 \%$

which is significantly less than that of the karstic zone, although still quite considerable; it indicates the relative hydrogeological importance of the detritic Weald and carbonate Jurassic formations.

If the whole catchment is considered:

$A P=244 \mathrm{hm}^{3}$

$R=73.6 \mathrm{hm}^{3}$

$T R P=R / A P=73.6 / 244=0.302$

$T R P=30.2 \%$.

This is the same as calculated by Sanz (1996) [16] for the water balance for a little more than six months in 1989.

\subsubsection{Discharges: Hydrological Regime of La Galiana}

Apart from the outflow of water that emerges from a cave on the left bank of the river Ucero-the so-called La Galiana spring, It was suspected that a hidden dis- 
charge of water also emanates through the river bed in the vicinity of this spring. In addition, there are discharges through the bed of the river Lobos, upstream of the spring, in the form of permanent pools connected to each other by a small stream of water in dry weather conditions, or by an appreciable current in times of mid to high water (between 10 and $60 \mathrm{l} / \mathrm{s}$ ).

For this reason, it was decided to install a flow gauge in the river Ucero, downstream of the spring, in the village of Ucero, where it was certain that all the groundwater discharge from the karst that drains via the rivers Lobos and Ucero could be quantified. This gauging station also records the surface inflows under spate conditions of the rivers Lobos and Chico, whose confluence lies upstream of the station. This had to be taken into account when separating the true groundwater component, an aspect that was achieved with some reliability, since both rivers have also been gauged.

Thus, the groundwater discharge of the Lobos and Ucero, arising mainly from La Galiana spring, both visibly and from the hidden inflow into the river bed, was monitored using a flow gauge located just above the bridge of the river in the village of Ucero, on a straight reach of the watercourse with a constant natural crosssection. The gauging site was the same as that used over 12 months for the hydrogeological study of Soria Province undertaken by Servicio Geológico de Obras Públicas (Public Works Geological Service) SGOP (1989) [15], which provided the ratings curve adopted in the present study, thus obtaining homogenous and comparative data with that year.

In this way, the hydrogram for the year 1995-1996 was reconstructed (1 Sept-31 August). This hydrogram is shown in Figure 6. The hydrogram approximates the surface component of spate flow of the river Lobos, so giving an estimate of the underground flow. This approximate calculation gives:

Flow of La Galiana spring = Allogenic flow-Flow of the river Lobos at Hontoria.

If this formula gives a negative result, it indicates losses in the river Lobos by differential gauging.

Considering only the subterranean discharges of the Ucero gauging station, the mean flow for the period considered was $2.689 \mathrm{l} / \mathrm{s}$, almost all of which derives from La Galiana spring, with only a small proportion coming from the Lobos discharges, some 4 to $5 \mathrm{~km}$ upstream of La Galiana. This mean flow is similar to that measured during the first half of 1989. According to Sanz (1996) [16], $25 \%$ of this corresponds to high flow and $75 \%$ to low flow, as surmised after applying a mathematical model to simulate the type of rainfall-runoff.

As shown in Figure 7, the La Galiana spring (1989 hidrogram) has quite an irregular flow that is quite sensitive to rainfall and snowmelt, which indicates rapid emptying of the aquifer. It should be noted that this variability corresponds to a period of around one year. Variability would be greater if there had been a longer flow series.

In both the 1995 and 1989 hydrograms, La Galiana spring reacts four or five days after significant rainfall. This time lag is logical in large karstic aquifers like this one, where there is a delayed reaction to recharge to allogenic streams situated on the periphery at moderate or long distance. Also to be taken into account is the $100 \mathrm{~m}$ or so mean thickness of the unsaturated zone that the allogenic recharge must penetrate, confirmed, to a certain extent, by the dripping from stalactites in the Lower cave at La Galiana after rainfall events (Sanz, 2000) [14].

The variation in spring flow during the emptying phase under a non-influenced regime can be expressed as follows:

$$
Q_{t}=Q_{o} \cdot e^{-\alpha t}
$$

or, in the form of Neperian logs:

$$
\operatorname{Ln} Q_{t}=\operatorname{Ln} Q_{o}(\alpha t)
$$

where

$Q_{t}$ is the flow of the spring at moment $t$.

$Q_{o}$ is the flow the spring at moment $t o$.

$\alpha$ is the recession coefficient.

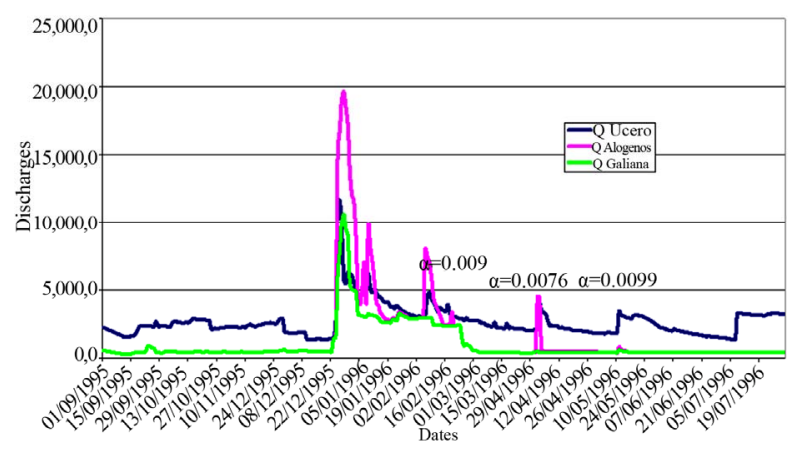

Figure 6. Hydrogram of the river Ucero at Ucero and of the total allogenic river flow for the year 1995-1996.

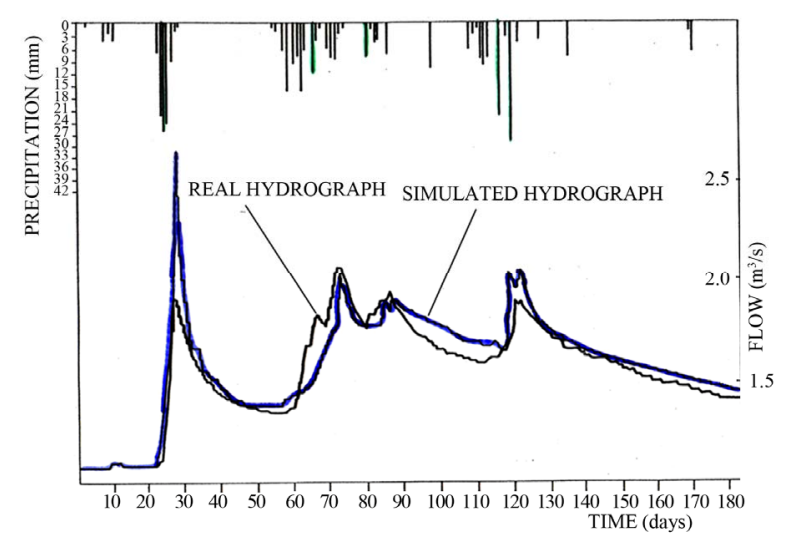

Figure 7. Real and simulated hydrogram for the year 1989. 
This is the expression that represents the law of receding flow in springs that drain confined or free aquifers of considerable thickness and that have a discharge point at a constant level, as in the case of the Ucero aquifer. The recession coefficient is constant and depends on the geometry of the aquifer $(L)$, its transmissivity $(T)$ and the storage coefficient $(S)$, so that:

$$
\alpha=(2 T) /\left(S L^{2}\right)
$$

where $L$ is the mean length of the aquifer, from the centre of gravity to the spring head.

Over the period for which the gauging data were available, the results were plotted on semi-logarithmic paper, looking for straight line segments during the periods without rainfall; i.e., periods corresponding to the recession curves. These straight line segments are reflected in the hydrogram in Figure 6.

The value of $\alpha$ is expressed by

$$
\alpha=\left(\operatorname{Ln} Q_{o}-\operatorname{Ln} Q_{t}\right) / t
$$

and in accordance with this, the following Table 2 was drawn up:

The three time windows considered are of similar length and the mean $\alpha$ is $\alpha=0.0085$ day $^{-1}$. In the 1989 hydrogram, the recession coefficient is somewhat larger $\left(\alpha=0.01\right.$ day $\left.^{-1}\right)$.

The expression obtained for the recession curve, expressing flows in $\mathrm{m}^{3} /$ day and time in days, starting on 14 June 1996, is

$$
Q_{t}=160,263 \cdot e^{-0,0085 t}
$$

In accordance with this, the following value is obtained for the water stored above the discharge elevation (hydrodynamic volume) for 14 May 1996:

$$
V=Q_{o} / \alpha=18.85 \mathrm{hm}^{3} \text {. }
$$

\section{RELATIONSHIP OF THE RIVERS LOBOS AND ITS TRIBUTARIES WITH THE AQUIFER WITHIN THE CANYON}

\subsection{Introduction: Hydrogeology and Karstic Canyons}

Canyons are an integral element of the geomorphology of calcareous mountains and mesetas, and their evolution over the Quaternary has impacted on the hydrogeology in ways that have not yet been adequately explained.

The mode of evolution of the walls of karstic canyons are determined by structural mechanisms and external morphoclimatic conditions, but also by the water circulation in the karst that influences the downwards linear development of a canyon. These subterranean flows depend on hydrological inflows to the karst and so are de-
Table 2. Different calculations of $\alpha$ in correspondence to different time periods and, hence, different $Q$.

\begin{tabular}{ccccc}
\hline Time period & $Q_{o}\left(\mathrm{~m}^{3} /\right.$ day $)$ & $Q_{t}\left(\mathrm{~m}^{3} /\right.$ day $)$ & $\Delta t$ (days) & $\alpha\left(\right.$ days $\left.^{-1}\right)$ \\
\hline $\begin{array}{c}20 / 02 / 96 \text { to } \\
30 / 03 / 96\end{array}$ & $261,169.9$ & $178,070.4$ & 40 & 0.009 \\
$\begin{array}{c}\text { 7/04/96 to } 10 / 5 / 96 \\
\begin{array}{c}\text { 14/06/96 to } \\
21 / 07 / 96\end{array}\end{array}$ & 1607,748 & 160,263 & 34 & 0.0076 \\
\hline
\end{tabular}

pendent on climate. There is a whole system of relationships that can be recognised in the Present Day and extrapolated back to the past. Although this is a general problem, it is particularly important in Mediterranean karst, given the variety of morphoclimatic and hydrological phases that are known since the onset of the Quaternary.

Large canyons that cross a karst region tend to be fed from surrounding mountains that are not calcareous, which supply abundant water with low carbonate content and that is aggressive.

Notwithstanding, there are numerous canyons excavated into karst massifs that are fed solely from rainfall infiltration, for which it is necessary to assume a wetter and more torrential climate in the past to explain their genesis. If the fissures of the surface karst are filled with terra rossa (or clays in general), impermeabilizing the watercourse, then there could also have been water circulation, at least seasonally. However, this process seems insufficient to explain rapid growth by mechanical erosion on the rocky canyon bottom. This also occurs in allogenic rivers which, on entering the karst, lose their erosive energy as the water infiltrates.

The bottoms of most Mediterranean canyons currently lie above the saturated zone of the karst and the permanent circulation level, so that it is frequent to find swallow holes, with surface water flow being limited to periods of high water (or even entirely absent).

Many canyons are accompanied at depth by a hypogeic network, or else there are short circuits in their meanders.

If the watercourses exist over lengthy periods, it is because of the abundance of their allogenic inflows, or to local circumstances, such as when a canyon falls largely within a syncline into which groundwater flows converge.

In contrast, the inflow of a watercourse flowing through the base of a karstic canyon is assured when the canyon bottom is close to the saturated zone. At this moment, permanent flows feed the canyon bottom through springs at the foot of the canyon walls, or where the phreatic level is higher than the stream bed. If canyons do not have this inflow, they will be dry. 
The presence in most canyons of ancient orifices transformed as shelters or hanging caves at various levels indicate the role, at various times, of karstic flows feeding the watercourse in the canyon, which acted as the principal drain.

In wet periods, inundation of the internal karst could mean that groundwaters would appear through the canyon bottom, allowing vertical erosion of the same. In contrast, during dry periods, such as in the Present Day, surface erosion can decrease and, with it, the vertical development of the canyon and the development of hypogeic watercourses. It could be that this occurs in the tributary streams rather than in the main canyon, leaving these affluent watercourses hanging to an increasing degree.

\subsection{Hypothesis Regarding the Hydrogeological Function of the River Lobos during the Quaternary}

Judging from the level of the erosion surface of the meseta (SEF) at about $1100 \mathrm{~m}$, the downcutting of the river Lobos certainly began at the end of the Miocene.

Given the equilibrium curves of the Lobos and its tributaries, which are all smooth and with no breaks, it can be assumed that the entire surface network evolved, in equilibrium with its valley downstream (the Ucero valley) at the same time as the downcutting of the Lobos. This would also have given hydrogeological stability through the Quaternary period, and a functioning similar to that of the Present Day.

During the Quaternary, the river Lobos would have been eroding the Ucero and Aylagas anticline, whose northerly flank acts as a barrier to the aquifer, with the point of lowest elevation always acting as the main groundwater discharge point of the aquifer. This cannot have changed substantially up to the Present (Figure 8).

The velocity of downcutting during the Quaternary is indicated by the situation of the erosion surface of the meseta (SEF) and of the terraces of the Ucero; in the Lobos, only one remnant of the T1 $(+10-15 \mathrm{~m})$ is conserved inside the cave of San Bartolomé ("de la Capilla").

Each terrace represents a period of stability in base level of the river, which in turn, determines the situation of the phreatic level, which was lowering over time together with the river Lobos. The permanent reserves of the aquifers also diminished as the saturated zone reduced during the downcutting, as the thalweg of the river approached the impermeable base of the aquifer. This, added to the increasing karstification over time, increased the variability in the subterranean drainage, and a loss in its regulation capacity.

As described above, each terrace level denotes a period of stabilization during which downward growth of swallow holes was detained. So, for example, today, there are sinkholes that terminate at the phreatic level, like the $104 \mathrm{~m}$ deep Valdecea. This does not mean that this swallow holes formed only recently, but rather that is has always been growing. It appears that there are other sinkholes that, once they reached the old phreatic level, did not deepen further when the rapid downcutting of the river Lobos began following a period of terrace-building.

If the sinkholes and terraces are projected on the same vertical plane, the situation of La Galiana caves are also highly significant, since they indicate the levels of former outpourings, all situated close to the permeable-impermeable edge of the northern flank of the Aylagas anticline described above (Figure 9). These all have the same orientation, parallel to the impermeable border, which indicates a highly constant paleoflow.

Another general feature, and one in which all the speleological descriptions accord (Hernanz and Navarro, 1973) [17], is that the cavities present at higher elevations (above $1050 \mathrm{~m}$, for example) show symptoms of decalcification, which means that they are ancient cavities, with speleothems that are dissolving now that they are in an aerated environment, where vertical water flow derives mostly from rainfall (aggressive water).

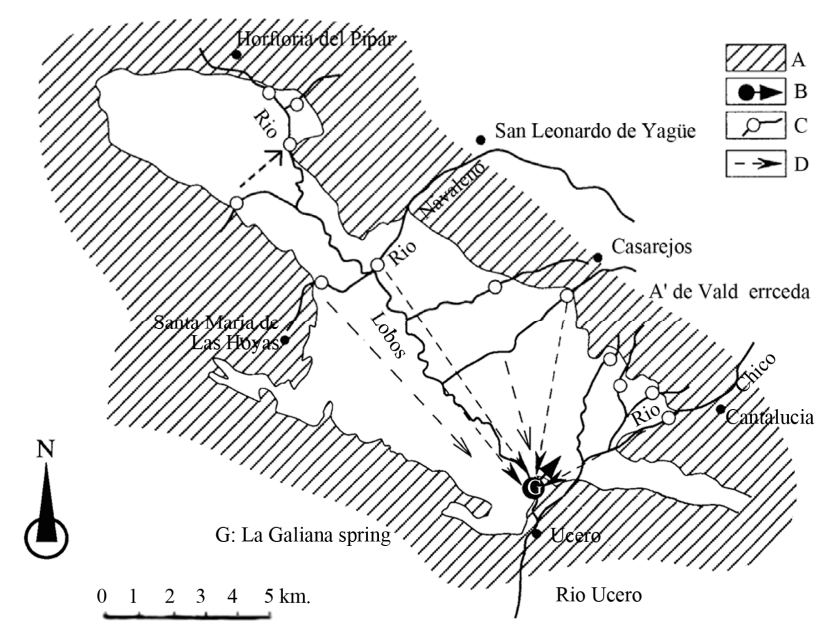

Figure 8. Hydrogeological scheme of the aquifer of the Lobos River Canyon and groundwater, showing the location of the gauging stations installed and paths tested with tracers. A. Non-karst rocks. B. La Galiana spring. C. Connection proven by tracer. D. Streams with sinks. E. Gauging stations.

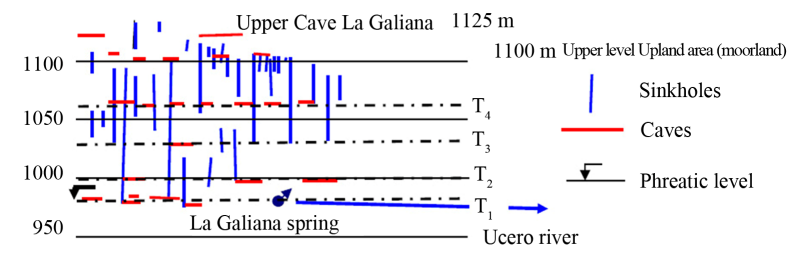

Figure 9. Location of caves and horizontal reaches of the sinkholes of the karstic system coinciding with the terraces of the rivers Ucero and Lobos. 
Recharge to the aquifer from allogenic rivers appears to be similar to the Present Day. One needs to imagine the beginning of the canyon, with no great differences in elevation, when the river Lobos formed in the centre of the synclinal. Groundwater flow would converge on this point, meaning that the river would carry water over long periods, so assuring water erosion and downcutting of the valley. During dry periods, the discharge would be like the Present Day, in the zone of La Galiana. Thus, it would have been conditioned by the barrier formed by the impermeable base, as the marly layers of the northern flank of the Aylagas-Ucero anticline were uplifted (Figure 10). Other discharges, like the transfers from the Tertiary, would not have been eroding strongly at this stage.

\subsection{River-Aquifer Relationships in the Karstic System in the Present Day}

We considered it appropriate to classify the hydrogeological regimes of the rivers and streams into three groups, according to the type of flow: low, medium or high water (corresponding to drought/dry season, intermediate, and spate flow). Obviously, this is not a strict delimitation and there are intermediate states. In addition, the streams can be variable and can behave independently of each other. Nonetheless, in general, we can say that the streams accord with this classification.

We consider that the natural recharge of streams is of great interest, particularly in arid countries like Spain, where watercourses are often losing streams as a result of the insufficient rate of recharge.

Low-water (dry season) regime (Figure 11).

This situation is very frequent and sometimes extends not only through the summer months, but also over long periods through the rest of the year. In this situation, the only rivers that carry water are.

River Lobos, upstream of Hontoria del Pinar (Burgos). It is lost through the river bed at the entrance to the Canyon, where one can actually see the flow diminishing as the water penetrates the gravels and the river banks.

The river Lobos had a mean flow of $92.3 \mathrm{l} / \mathrm{s}$ over the period monitored. Flows are generally less than $30 \mathrm{l} / \mathrm{s}$ but

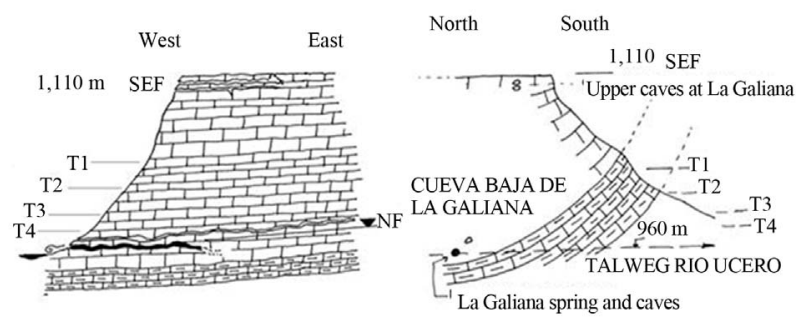

Figure 10. N-S and E-W profiles of the La Galiana geology, showing location of caves, phreatic level and the spring at La Galiana.

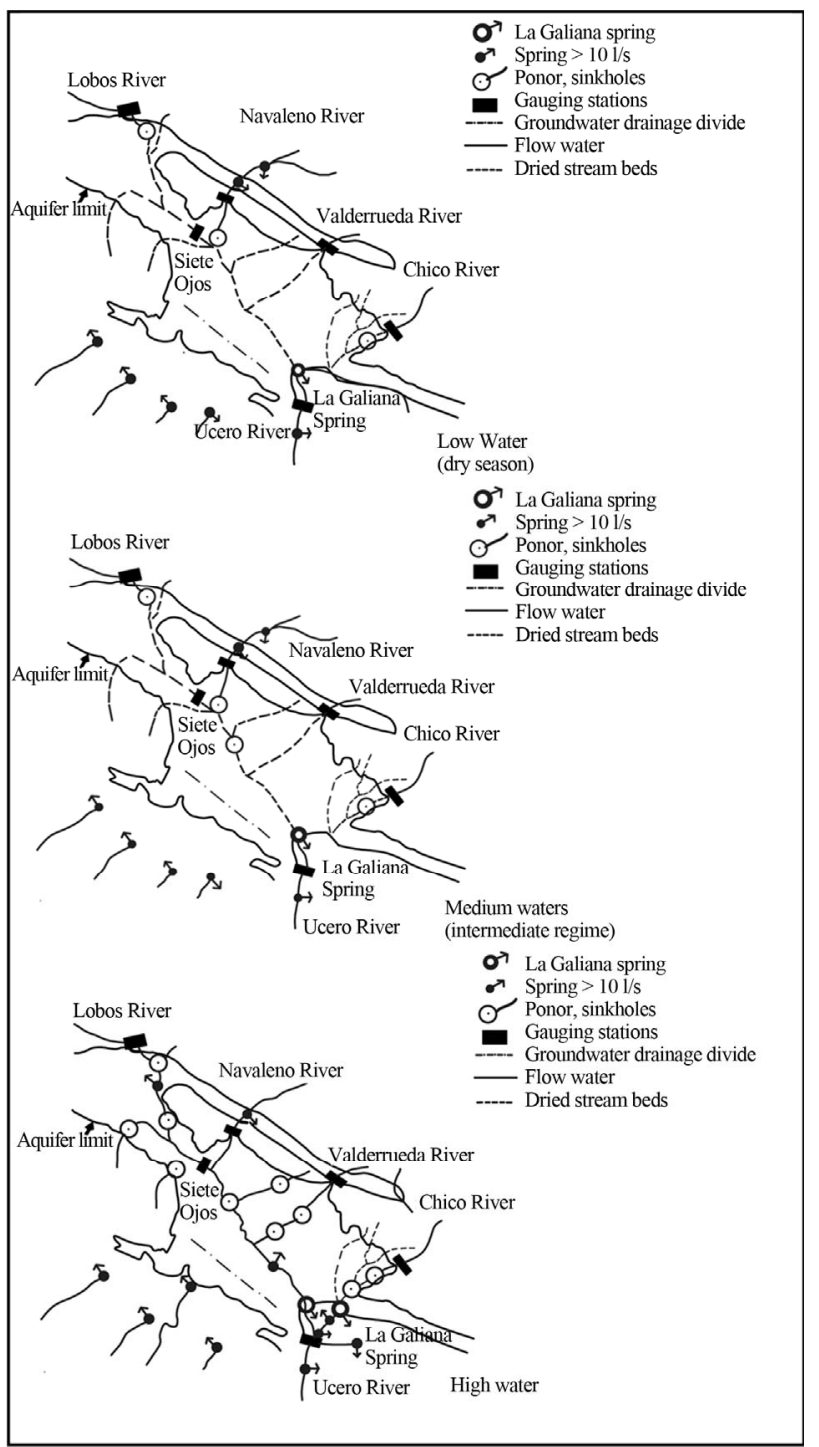

Figure 11. Summary scheme of the hydrogeological behaviour of the river Lobos and its tributaries during high, medium and low water periods.

the mean was considerably raised by the effect of the spate floods during December 1995.

Over the study period, in the $11 \mathrm{~km}$ reach between Hontoria del Pinar and Puente de Siete Ojos, the river was basically a losing stream, whereby for $82 \%$ of the time (279 days), no water flowed under the Puente de Siete Ojos. The water infiltrated, instead, through the sinkholes (such as Apretadero where more than 400 1/s can be lost).

River Navaleno, which flows from San Leonardo and Navaleno, where there are various tributaries with permanent flow from the Wealden Facies. The flow swells due to the karstic flows of San Leonardo de Yagüe, by an estimated $40-59$ 1/s mean flow, fed from the Jurassic carbonate mountains. The Navaleno disappears under low water conditions below Arganza, both diffusely 
through its gravel bed and through discrete whirlpools. The point where the river is lost varies as a function of river flow, but it is generally dry before it reaches its confluence with the river Lobos.

Over the period of study, the period of loss in the river Lobos lasted at least 273 days, or $80 \%$ of the time. The mean flow in the Navaleno was $759.7 \mathrm{l} / \mathrm{s}$. When the river carries less than $1000 \mathrm{l} / \mathrm{s}$, it does not reach Ucero via the river Lobos (although this does vary depending on whether the phreatic level is high or low).

The river Chico has a permanent base flow of some 60 $1 / \mathrm{s}$, and is lost downstream of Talveila village. However, this point too, is variable depending on the flow in the river. The number of days that there is flow in the river at the confluence at Ucero river is unknown but it must be very few.

The Valderrueda stream normally carries a flow of a few litres per second, which is lost in the stream bed as it enters the carbonate outcrops. However, on many occasions, the flow is lost through the gravel bed, even before reaching these outcrops. Over the period surveyed, there was a flow on 223 days, i.e., $65.3 \%$ of the time.

The outflows of the karstic system under a low-water regime are limited to the spring at La Galiana (where it emanates in the cave as well as from hidden outflows in the river Ucero), and from the permanent pools in the river Lobos between the San Bartolomé hermitage and as far as the confluence with the Ucero. These ponds are normally connected by a stream with less than $10 \mathrm{l} / \mathrm{s}$; really, this discharge is the same as that in La Galiana. Outside the Lobos itself, are the springs of Rojas, Santervás, Fuencaliente and Ucero, which have a permanent joint flow of 50 to $70 \mathrm{l} / \mathrm{s}$.

Hydrological regime in "medium waters" (intermediate regime) (Figure 11).

This regime also occurs quite frequently, and is similar to the low water regime. It differs from that in that when the River Lobos carries more than about $200 \mathrm{l} / \mathrm{s}$, the flow disappears down a sinkhole $1 \mathrm{~km}$ from Hontoria del Pinar at a place called Apretadero.

When the river Navaleno carries more than about 500 $1 / \mathrm{s}$, it also disappears 1 or $2 \mathrm{~km}$ further downstream, in a swallow hole in the bed of the Lobos.

The Valderrueda stream is lost in the calcareous outcrops, downstream of the road bridge, at a variable point that is dependent on the actual flow.

The disappearance of the river Chico is also displaced downstream by half a kilometre under medium-water conditions. In Medieval times there were mills located along the whole of the river taking water. They functioned by covering the swallow holes and sinks in the river bed, so that the surface water reached as far downstream as the river Ucero. This arrangement also meant that the valley of the Chico could be irrigated from the river.

Nowadays, there are only a few occasions when the river reaches the confluence at Ucero, when the river is in spate. Frequently the river is dry at Cantalucía.

The springs at Rejas, Santervás, Fuencaliente and Ucero do not increase their flow significantly under this regime.

The flow in the river Lobos increases a little in its lower reaches.

High-water Regime.

In rainy spells or periods of snowmelt, the Lobos and its tributaries of Lobos swell considerably, and some can even be flowing after they have passed over the aquifer outcrops.

In spate, the river Lobos carries flow beyond the swallow holes at Apretadero, under the Siete Ojos Bridge and as far as La Galiana. During the 1995-1996 monitoring period, this occurred on 62 days (Figure 12). When it happens, it seems that the Lobos is a losing stream in its headwaters and a gaining stream in its downstream third. The temporal hanging springs of Raideras appear at the head of the canyon, draining a syncline. These can contain more than $400 \mathrm{l} / \mathrm{s}$ and flows over several weeks.

There are also resurgences in the lower part of the canyon, close to La Galiana (next to the café-bar), of 50 - 60 $1 / \mathrm{s}$. On the periphery of the system, the Valdeavellano spring in Ucero emerges in a cave, with a flow of some 50 - 100 1/s. Another stream comes from the ephemeral spring of the Hue Seca de Santa María de los Hoyas.

The river Navaleno reaches its confluence with the Lobos, as do the Valderrueda, Chico and others.

There are some watercourses that are almost always

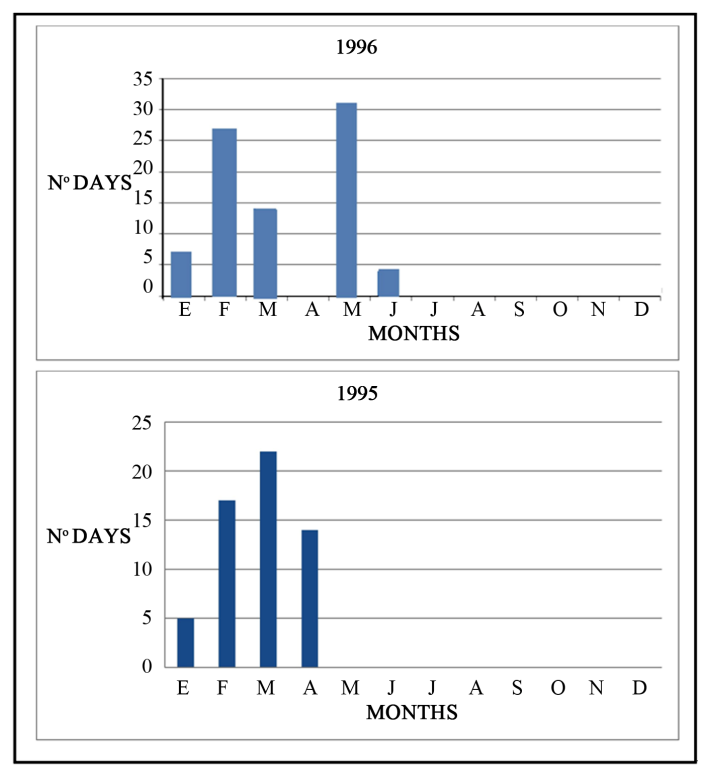

Figure 12. Number of days per month when water flowed at Seven Eyes Bridge, during 1995 and 1996. 
dry, which give rise to losing streams in Herrera, of which the most spectacular is the stream of Santa María de los Hoyas, which completely infiltrates in a cave that closes a small valley.

Relationship of the river Lobos with the aquifer as observed using tracer tests.

Methodology was based on ten tracer tests. The tracer tests have been done following methodology of Käss (1998) [18]. They were carried out by dosing uranine in sinkholes. Distance was established between 5 and 14 km from each other. During years 1995 and 1996, tests were done. As per due, tests were done in both low water and flood conditions during the hydrological year. They included both severe low water and a sudden winter recharge. Finally a further test was done in the sporadic springs of Las Raideras via a connected sinkhole with the phreatic level at its base (Figures 2-5).

Under low water conditions, groundwater flow is towards La Galiana spring only, since the river Lobos re- mains dry over its entire length, except for a number of deep pools where the phreatic level comes to the surface, from downstream of the San Bartolomé hermitage, over a stretch of approximately $4 \mathrm{~km}$. The dye appeared only in La Galiana, in the form of a unimodal curve (Figures 13 and 14).

In times of intermediate flows, (neither dry season nor flood flows) which is the most common situation, the phreatic level rises and the lower reach of the river Lobos becomes a secondary surcharge for the aquifer, acting as a kind of overflow for La Galiana. This involves a flow between the pools of no more than $30 \mathrm{l} / \mathrm{s}$, since the majority of the flow continues to emerge via La Galiana. The rest of the river Lobos watercourse, upstream of the hermitage, is a losing stream. In the intermediate flow situations, dye also emerged in the river Lobos. When sampling was done in the river Ucero, downstream of La Galiana and the river Lobos, the response curves were bimodal, a smaller peak presaging these two outflow

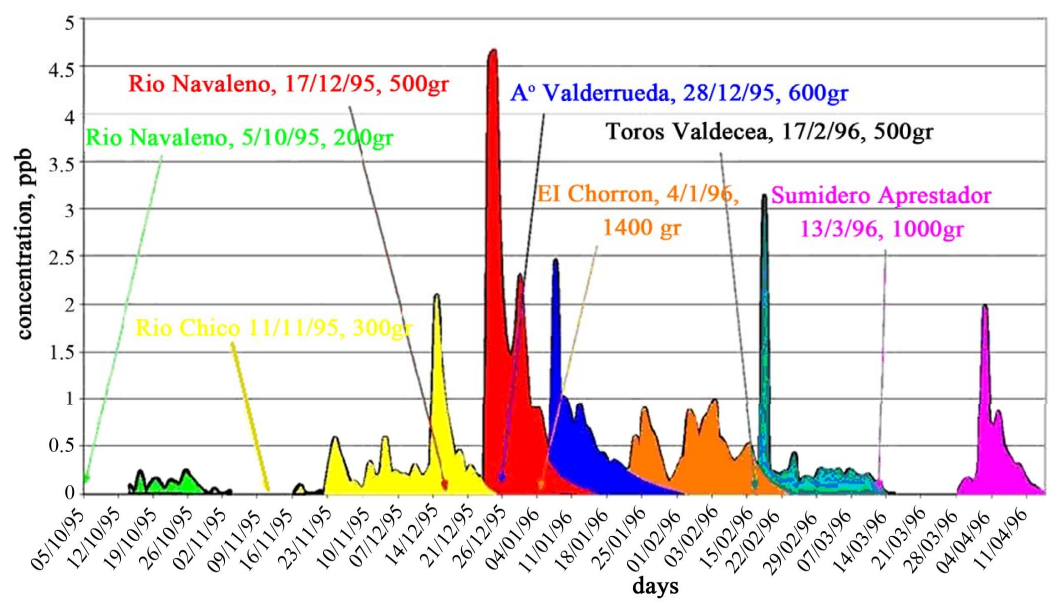

Figure 13. Response curves concentration-time for different tracer tests (Segovia et al., 2011).

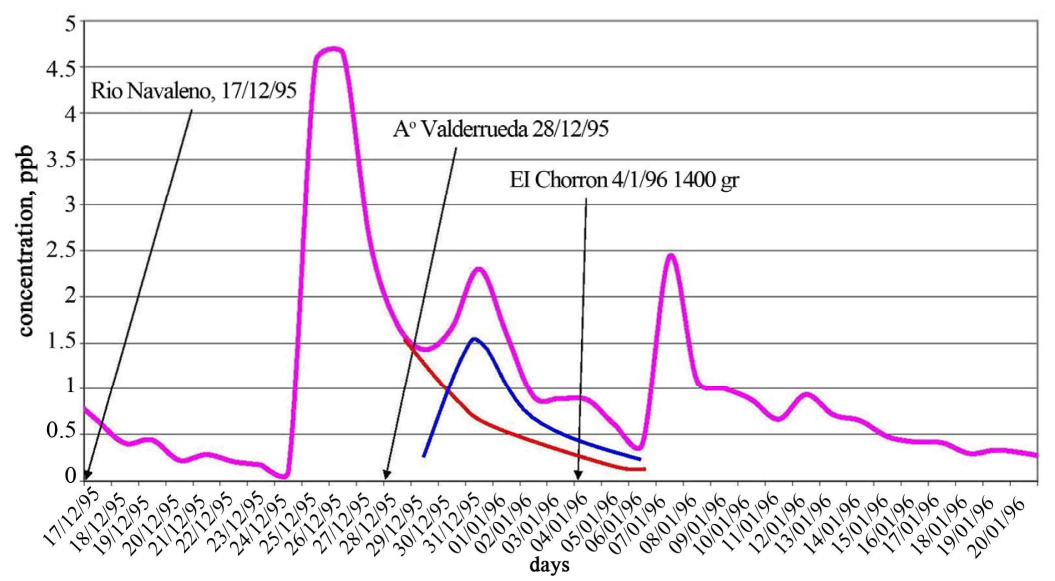

Figure 14. Response curve detailed at La Galiana spring and Lobos River for testing Navaleno River, Arroyo de Valderrueda and Chorrones sink (Segovia et al., 2011). 
plumes (Figure 14). When samples were taken in the river Lobos and at the Galiana spring, separately and together, it was observed that the tracer appeared first in the river Lobos and, later, at La Galiana. This makes sense, since the river Lobos sampling points are upstream of the spring. In the test where dye was injected into the Apretadero sinkhole, the delay at La Galiana with respect to the river Lobos was two days (Figure 15).

Under flood water conditions, the river Lobos contains water along the entire canyon. In its upstream $6 \mathrm{~km}$, between the head of the canyon and the Puente de Siete Ojos, the river now acts as a gaining stream. This occurs as a consequence of producing copious ephemeral surcharges that drain a hanging syncline. In 2000, a tracer test confirmed the existence of a rapid, local flow between the groundwater flow from a cave called Sima del Portillo de Hontoria to the principal of these springs (Las Raideras). In the reach between Puente de Siete Ojos and the San Bartolomé hermitage, more or less, the river is always a losing stream, as evidenced by differential gauging, and by the fact that the tracers did not appear here. The limit of the hermitage is approximate because, as the phreatic level rises again, it is the intersection between this and the watercourse that separates the losing and gaining parts of the river. As the river usually contains a great flow, it is difficult to appreciate this transition and the only way to check it is using tracers. Between the hermitage and La Galiana spring the river is a gaining stream, as shown by the appearance of the tracer substance.

Quantification of losses and discharges of the river Lobos with the karstic aquifer.

Whilst the hydrogeological behaviour of the river Lobos is described above, this section elaborates its relationship to the karstic aquifer.

The first step was to compare flows at the gauging stations of the Lobos at Hontoria del Pinar and Puente de Siete Ojos, to determine if flow is being lost or gained.

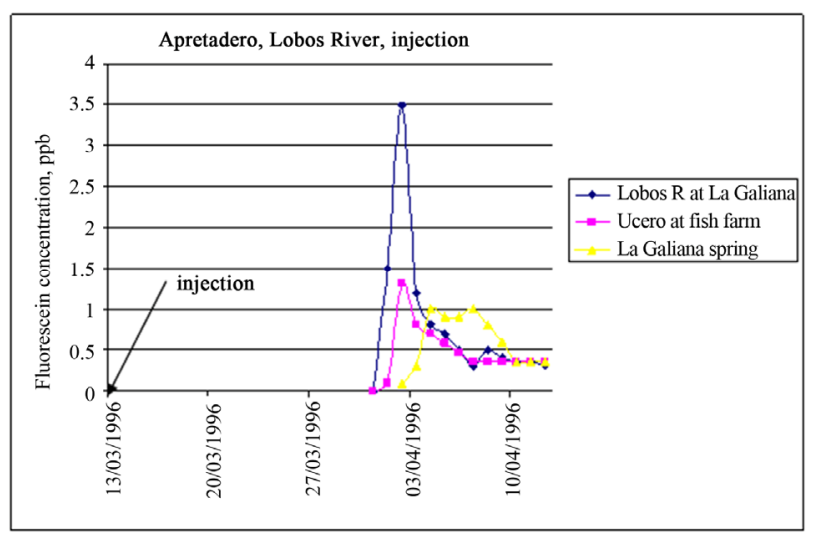

Figure 15. Concentration-time in response for test in Lobos River, Apretadero sink place (Segovia et al., 2011).
During high spates, like that of December 1995, the river is clearly gaining flow, with more flow downstream (Puente de Siete Ojos) than upstream (Hontoria del Pinar).

Between 25/12/95 and 17/1/96 (which is when flood flow ceased and the Navaleno resumed its base flow of $181 \mathrm{l} / \mathrm{s}$ ), the flow at Siete Ojos Bridge was $8,671,795 \mathrm{~m}^{3}$, At Hontoria it was $2,360,793 \mathrm{~m}^{3}$, and so the difference $\left(6,311,002 \mathrm{~m}^{3}\right.$ equivalent to a mean flow of $\left.3.044 \mathrm{l} / \mathrm{s}\right)$ is the water that emerged into the river over this reach. Differential gauging showed a peak discharges of up to $7000 \mathrm{l} / \mathrm{s}$.

The confirmed point of greatest discharge corresponds to Las Raideras, which discharged more than $400 \mathrm{l} / \mathrm{s}$ during a small spate. It is probable that water also emanates in other reaches of the river.

Las Raideras usually appear suddenly, in the form of ooutpourings, and they flow for days, weeks or even months. They represent the discharge of a quasi-hanging syncline situated on the left bank. Over the winter of 1995-1996, they flowed for 34 days.

Las Raideras empty very quickly, as determined by differential gauging. The coefficient of recession is:

$$
\begin{aligned}
& Q_{o}(9 / 1 / 96)=6,5001 / \mathrm{s}=561,600 \mathrm{~m}^{3} / \text { day } \\
& Q_{o}(26 / 1 / 96)=1001 / \mathrm{s}=8,640 \mathrm{~m}^{3} / \text { day } \\
& (t) \text { time }=17 \text { days } \\
& \alpha=\left(\operatorname{Ln} Q_{o}-\operatorname{Ln} Q_{t}\right) /(t)=13.2-9.06 / 17=0.24 \text { day }^{-1}
\end{aligned}
$$
where

The hydrodynamic volume $(V)$ on $9 / 1 / 1996$ was:

$$
\begin{aligned}
& V(9 / 1 / 1996)=Q / \alpha=561.600 \mathrm{~m}^{3} / 0.24 \mathrm{day}^{-1} \\
& =2,340,000 \mathrm{~m}^{3}
\end{aligned}
$$

This volume emptied in 18 days, though the contribution recorded at Puente de Siete Ojos was only $1,296,000 \mathrm{~m}^{3}$, or less than half the volume, which suggests that there are significant losses during spate periods between these two points.

A similar situation occurred in February 1996 over 13 days, when this reach of the river registered peak flows of more than 5000 l/s. In April and May of the same year, shorter periods of the same phenomenon occurred.

Loss of flow was estimated to be 7000 1/s (Qmáx) over approximately $8 \mathrm{~km}$.

Even so, when the Lobos is not in spate, this reach of the river is basically a losing stream. Thus, in the period of study, this phenomenon occurred on 279 days (82\% of the time), where Las Raideras, although they may have been flowing, would have had only a small flow that was lost in the Apretadero swallow hole (peak capacity 400 $1 / \mathrm{s})$.

The hydrogeological behaviour of the rest of the river will now be described.

The differential gauging between Puente de Siete Ojos and Ucero, $2 \mathrm{~km}$ apart, show that it loses flow under all 
conditions, except in the last $2-4 \mathrm{~km}$, where is can be moderately gaining. (Even this reach can reduce to no more than $1 \mathrm{~km}$ under low flow conditions).

For 16 days during the flood of December 95-January 96, flows in the Ucero station were lower than at Puente de Siete Ojos, indicating that some flow infiltrated through the riverbed to recharge the aquifer. Mean daily flow differences of up to $8000 \mathrm{l} / \mathrm{s}$ were calculated (i.e., lower than the $18,000 \mathrm{l} / \mathrm{s}$ peak flood flow)), which is equivalent to a recharge of $571 \mathrm{l} / \mathrm{s} / \mathrm{km}$.

Over these few days, the aquifer was recharged with $5,110,733 \mathrm{~m}^{3}\left(5.1 \mathrm{hm}^{3}\right)$ over $14 \mathrm{~km}$ watercourse.

The phenomenon was repeated over 8 days from $5 / 02 / 1996$ to $12 / 02 / 1996$, with a recharge of $1,160,525$ $\mathrm{m}^{3}$; and again on the 19/02/1996 and for 2 days in April 1996.

Nevertheless, the most common situation is for the river Navaleno to penetrate into the course of the Lobos to a certain extent (depending on the flow it carries). Thus, over the study period, with the river Lobos dry at Puente de Siete Ojos, the river Navaleno had a flow of 2000 to 3000 1/s at Arganza gauging station over 20 days. This flow was completely lost in the sinkholes of the Lobos $1.5 \mathrm{~km}$ downstream of Puente de Siete Ojos.

On other occasions when there is more flow, the river flows along its entire length - which seems to pose a contradiction. This variation of recharge over time is undoubtedly due to the position of the phreatic level. After a prolonged drought (like the one preceding the spate conditions of winter 95/96) a low water table allows massive recharge with peak daily flows exceeding $8000 \mathrm{l} / \mathrm{s}$. However, the response of the water table is very rapid, as confirmed from an incomplete borehole in the river bed at Puente de Siete Ojos, where it rose more than $20 \mathrm{~m}$ in a matter of days, rising to the level of the riverbed itself. By this means, the amount of recharge could fall substantially.

Hydrological interruptions caused by the sudden formation of swallow holes.

Until this point, hydrological variations in the surface drainage network have been considered solely as a product of the flow variations arising from precipitation and the location of the phreatic level. We have assumed that the characteristics of the alluvial surface do not vary and that the river Lobos sometimes hangs with respect to the phreatic level because its bed contains clayey sediments. This layer of sediment isolates the river from the aquifer, but if it ruptures, it causes collapse of the river bed and the formation of sinkholes. The sinkholes persist over long periods, since to plug them requires much more clay sediment. These collapses are dramatic upsets to the normal hydrological regime but they highlight the role of the fluvial deposits. These phenomena are rare and largely unpredictable in both space and time but, of course, they are possible over long periods. Over twenty years of visual monitoring, only one phenomenon has been observed in the river, which we will now describe:

In 2008, after a prolonged period of drought, the bed of the river Navaleno suddenly collapsed, giving rise to a swallow hole that consumed the entire flow of the river (200 1/s), leaving the river bed downstream completely dry over a reach of $3 \mathrm{~km}$. For a period of several days, small alluvial collapse dolines appeared in the vicinity related to the same phenomenon, through which one could hear the sound of water flowing at depth. The collapses revealed the limestone, which was seen to be intensely karstified. As the phreatic level fell during the drought, the ceilings of the cavities lying beneath the river, normally full of water, were left without any resistance, and the collapses were produced as a consequence (Figure 16).

River regime in the Wealden and Jurassic aquifer.

As mentioned above, the river Lobos had a mean flow of $92.3 \mathrm{l} / \mathrm{s}$ over the period recorded, though it generally contains flows of less than $30 \mathrm{l} / \mathrm{s}$ : the spates during December 1995 are responsible for raising the mean. It is noticeable that a catchment of $80 \mathrm{~km}^{2}$ has such a low flow. If the flows corresponding to the spate periods are removed, one can say that all the inflows are subterranean, oscillating between 40 and $10 \mathrm{l} / \mathrm{s}$, with only slight variation.

The flow gauging surveys allowed stretches exhibiting flow recession to be identified, so that recession curves could be drawn.

One representative period was between $26 / 8 / 95$ and 14/10/95.

According to Eq.1,

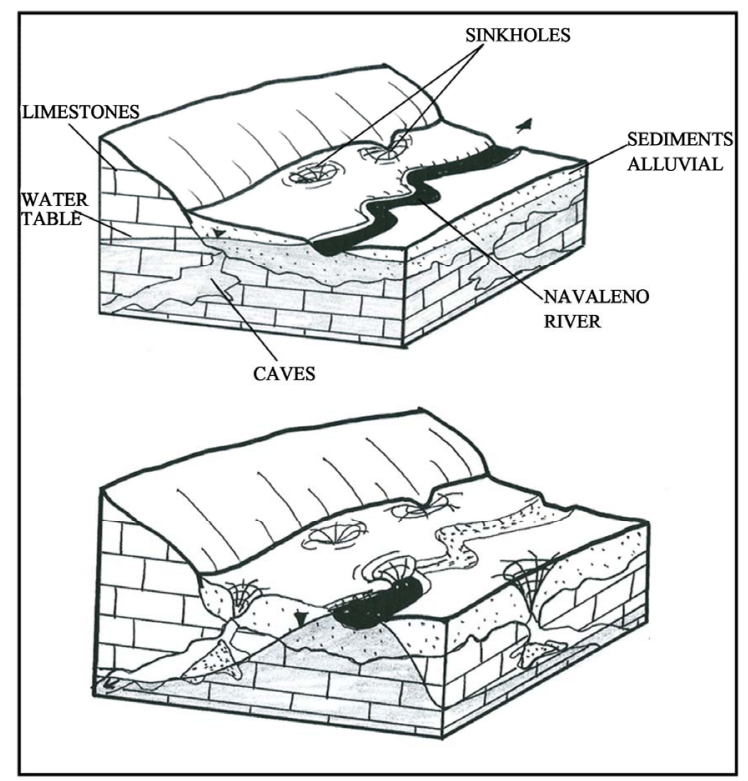

Figure 16. Navaleno river interruption caused by the sudden formation of sinkholes in 2008. 
$Q_{t}(26 / 8 / 95)=39 \mathrm{l} / \mathrm{s}=3369 \mathrm{~m}^{3} /$ day

$Q_{t}(14 / 10795)=51 / \mathrm{s}=432 \mathrm{~m}^{3} /$ day

$t=50$ days

$\alpha=\left(\operatorname{Ln} Q_{o}-\operatorname{Ln} Q_{t}\right) / t=(8.1-6.06) / 50=0.04$ day $^{-1}$

the hydrodynamic volume $(V)$ on $14 / 10 / 95$ was $V=Q_{t}=$ $432 / 0.04=10,800 \mathrm{~m}^{3}$.

The river Navaleno has the same surface catchment area, with similar terrain, land-use, altitude and rainfall, shows a mean flow of $759.7 \mathrm{l} / \mathrm{s}$, i.e., more than seven times as much as the Lobos. This difference may partly be explained by the following factors (though undoubtedly others are involved as well):

1) The recharge area of the strip of limestones and dolomites is larger in the Lobos catchment than in the Navaleno one, occupying over $50 \%$ of its surface. Here, there are no significant outpourings; rather, the flow is directed towards the Navaleno, at lower altitude, where there are significant surgences. It seems that there is a natural underground transfer.

2) The syncline that forms the structure of the Wealden occupies both catchments, occurring at a lower elevation in the Navaleno, which must determine that the flow is directed here.

A characteristic recession curve has been identified between $1 / 9 / 95$ and $21 / 10 / 95$

$$
\begin{aligned}
& \alpha=\left(\operatorname{Ln} 37,760 \mathrm{~m}^{3} / \text { day }-\operatorname{Ln} 21,686\right) / 51 \text { days } \\
& =0.0023 \mathrm{day}^{-1}
\end{aligned}
$$

with a hydrodynamic volume $(V)$ on $21 / 10 / 95$ of

$V=Q_{t} / \alpha=21,686 / 0.0023=9.4 \mathrm{hm}^{3}$.

The low value of the recession coefficient is noteworthy and the considerable water reserves held above the discharge points.

Whilst there was no continuous flow record for the river Chico, point measurements were sufficient to derive its recession coefficient, using flows for $26 / 8 / 95$ and 5/10/95.

$$
\begin{aligned}
& \alpha=\left(\operatorname{Ln} 12960 \mathrm{~m}^{3} / \text { day }-\operatorname{Ln} 8501.7 \mathrm{~m}^{3} / \text { day }\right) / 41 \text { days } \\
& =(9.46-9.04) / 41=0.01 \text { day }^{-1}
\end{aligned}
$$

with a hydrodynamic volume on $5 / 10 / 95$ of $V=0.8 \mathrm{hm}^{3}$.

The mean flow of the river Chico was estimated to be $113.6 \mathrm{l} / \mathrm{s}$, constant and regular. It does not generally fall below $50-60$ 1/s.

The Casarejos stream had running water on 223 of the 341 days measured, giving a mean flow of 84.6 1/s. Virtually all the flow comes during spate periods, since the habitual flow is less than $5-10 \mathrm{l} / \mathrm{s}$.

\section{CONCLUSIONS}

The methodology proposed consists of conventional hydrogeological methods (inventory of water points) field observations of the hydrogeological behaviour of rivers, tracer tests, flow measurements of surface water inflows, river flows and outflows from the karstic system, as well as differential river gauging and measurement of groundwater discharges from the aquifer. Its application enabled the principal characteristics about the River Lobos and its associated aquifer to be understood in a short period and it established a water balance for the year 1995-1996. The methodology applied has given good results, yielding quite a clear conceptual model of the hydrogeological operation of the rivers.

This aquifer covers a surface area of $164 \mathrm{~km}^{2}$, with a further $197 \mathrm{~km}^{2}$ over several peripheral catchments of less permeable outcrops that provide the allogenic river flows that infiltrate into the karst. The karstic aquifer is defined by a hydrostratigraphic unit of limestones dating from the Upper Cretaceous. It is $240 \mathrm{~m}$ thick and overlies an impermeable basement of marls from the same geological era. The geometry of the aquifer is a synclinorium oriented west-northwest to east-southeast, and the marls also form its lateral boundaries. The circulation of ground-water, confirmed using tracers, is governed by the large syncline towards La Galiana spring and the lower reaches of the river Lobos, where La Galiana spring, the principal discharge of the system, is located.

The essential features of the hydrogeological functioning of this karstic system seem to have been maintained throughout the Quaternary.

During wetter periods in the past, the river Lobos, cut into the heart of the syncline, must have taken on greater importance as a linear collector of the subterranean drainage in the karst. In contrast, during dry periods like the Present Day, the phreatic level lies below the river bed for most of the time and over most of its length. Currently, the Lobos represents an axis of linear recharge for the surface runoff arising in the surrounding allogenic catchments. This recharge capacity, although variable through time (depending on the level of the water table), can exceed $8000 \mathrm{l} / \mathrm{s}$, or $571 \mathrm{l} / \mathrm{s} / \mathrm{km}$. It is only when these flows exceed the watercourse's capacity for recharge that water flows out of the system via Ucero. In dry weather (low water) periods, and in the lower reaches, the water table comes to the surface in the deep pools (which assume great ecological importance). During periods of high water, the river continues to be a losing stream along most of its length, with the exception of the headwaters of the Canyon (where Las Raideras springs can resurge) and in the lower reach (where the length of gaining stream increases quite markedly). Las Raideras are sporadic discharges of local flow, a product of the rapid and sharp rises in phreatic level.

In the hydrological year 1994-1995, groundwater discharges had a mean flow of $2.423 \mathrm{l} / \mathrm{s}$, highly variable and with a hydrodynamic volume at the onset of emptying $(17 / 07 / 1996)$ of $V=18.85 \mathrm{hm}^{3}$. The water balance 
cal- culated for this period (during which the aquifer was under a natural regime) gave the rainfall input to be $109.5 \mathrm{hm}^{3}$, with a natural recharge of $73.6 \mathrm{hm}^{3}$, evapotranspiration of $67.7 \mathrm{hm}^{3}$, with practically non-existent surface runoff, lateral transfers to other aquifers and zero pumped abstractions. The increase in water in the aquifer was $5.59 \mathrm{hm}^{3}$.

Since it was possible to gauge flows at temporary stations on the allogenic rivers, it was possible to differentiate between allogenic and autogenic recharge. Over the period considered, the diffuse or autogenic recharge was estimated to be $41.8 \mathrm{hm}^{3}$, which represents $56.8 \%$ of the total. Allogenic recharge arises from losses from the allogenic rivers from catchments on the north and northeastern periphery of the aquifer. These catchments cover $197 \mathrm{~km}^{2}$, consisting of detritic Wealden terrains, with lesser outcrops of Jurassic carbonates. These watercourses were measured at temporary gauging stations; revealing contributions of $31.8 \mathrm{hm}^{3}$, or $43.2 \%$ of the total recharge. The regime of the allogenic rivers show an appreciable and relatively constant base flow. Over the Lobos catchment as a whole, recharge for the period considered was $R=73.6 \mathrm{hm}^{3}$, or $30.2 \%$ of the precipitation. In the karstic zone, recharge was $R_{k}=38.2 \%$ and in the allogenic zone, $R_{w}=24 \%$.

\section{ACKNOWLEDGEMENTS}

We should like to thank the director of the Natural Park of the River Lobos Canyon, Don José Manuel Meneses Canalejo, for all the help given during field studies, from assistance obtaining necessary permissions, to help from the Natural Park rangers for water sampling during the tracer tests, taking reading at the gauging stations that they installed, etc.

These studies were undertaken as part of the Research Project AMB95-0154: "Hydrodynamic function and pollutant propagation in the karstic aquifer of the Natural Park of the river Lobos Canyon (Soria-Burgos)".

We also thank the Fundación Juan Miguel Villar Mir that through the Research Agreement on bibliographical and material located at the Museum of Geology (Laboratorio de Geología. Escuela de Ingenieros de Caminos de Madrid) we could obtain two previous qualitative tests tracers that they were used to plan the recent campaigns, as well as support of this work.

\section{REFERENCES}

[1] Barlow, P.M. and Dickerman, D.C. (2001) Numerical-simulation and conjuctive-Management models of HuntAnnaquatucket-Pettaquamseutt Stream-Aquifer System, Rhode Island. US Geological Survey Professional Paper, 1636.

[2] Granato, G.E., Barlow, P.M. and Dickerman, D.C. (2003) Hydrogeology and simulated effects of ground-water withdrawals in the Big River Area, Rhode Island. US Geological Survey Water-Resources Investigations Re- ports, 03-4222.

[3] Scalon, B.R., Mealy, R.W. and Cook, P.G. (2002) Choosing appropriate techniques to estimate groundwater recharge. Hydrogeological Journal, 10, 18-39. doi:10.1007/s10040-001-0176-2

[4] Kalbus, E., Reinstorf, F. and Schirmer, M. (2006) Measuring methods for groundwater-surface water interactions: A review. Hydrology and Earth System Sciences, 10, 873- 887. doi:10.5194/hess-10-873-2006

[5] Lerner, D.N., Issar, A.S. and Simmers, I. (1990) Groundwater recharge, a guide to understanding and estimating natural recharge. International Association of Hydrogeologists, International Contribution to Hydrogeology, Hannover.

[6] Abdulrazzak, M.J. and Morel-Seytoux, H.J. (1983) Recharge from an ephemeral stream following wetting front arrival to water table. Water Resources Research, 19 194-200. doi:10.1029/WR019i001p00194

[7] Freyberg, D.L. (1983) Modeling the effects of a timedependant wetted perimeter on infiltration from ephemeral channels. Water Resources Research, 19, 559-566. doi:10.1029/WR019i002p00559

[8] Winter, T.C., Harvey, J.W., Franke, O.L. and Alley, W.M. (1988) Ground water and surface a single resource. US Geological Survey Circular, 1139.

[9] Stonestrom, D.A. and Constantz, J. (2004) Using temperature to study stream-ground water exchange. US Department of the Interior and US Geological Survey, 2004-3010

[10] Goodrich, D.C., Lane, L.J., Shillito, R.M., Miller, S.N., Syed, K.H. and Woolhiver, D.A. (1997) Linearity of basin response as a function of scale in a semiarid watershed. Water Resources Research, 33, 2951-2965. doi:10.1029/97WR01422

[11] Segovia, R., Sanz, E. and Menéndez-Pidal, I. (2011) Contribution of tracer for understanding the hidrodynamics of karstic aquifers crossed by Allogenic Rivers, Spain Hydraulic Conductivity Issues, Determination and Applications, 247-266. doi:10.5772/22093

[12] IGME (1956) Mining and Geological Spanish Institute. Spanish Geological Map. E: 1/50.000 (Old Serie). Sheet 350. Memory of Fuentearmegil.

[13] IGME (1982) Mining and Geological Spanish Institute. Spanish Geological Map. E: 1/50.000 (Old Serie). Sheet 349. Memory of Cabrejas del Pinar Map.

[14] IGME (1982) Mining and Geological Spanish Institute. Spanish Geological Map. E: 1/50.000 (Old Serie). Sheet 348. Memory of San Leonardo de Yagüe Map.

[15] SGOP (Servicio Geológico de Obras Públicas) (1989) Hidrogeological Statement in Soria Province. Unpublished Survey.

[16] Sanz, E. (1996) The Lobos River Canyon karst and its hydrogeological functioning. Karstología, 28, 45-56.

[17] Hernanz, A. and Navarro, J.M. (1973) La Galiana Cave, Ucero (Soria). Revista Celtiberia, 19, 87-92.

[18] Käss, W. (1998) Tracing technique in geohydrology. Rotterdam, Balkema. 